222

Received: October 24, 2016

Accepted: November 27, 2016
Macedonian Journal of Animal Science, Vol. 6, No. 2, pp. 107-112 (2016)

In print: ISSN $1857-6907$

On line: ISSN $1857-7709$

UDC: $334.722: 332.14 / .15(497.7-14)$

Original scientific paper

\title{
ENTREPRENEURSHIP IN RURAL COMMUNITIES OF THE SOUTHWEST PLANNING REGION IN THE REPUBLIC OF MACEDONIA
}

\author{
Tošo Kostadinov \\ Ss. Cyril and Methodius" University in Skopje, Institute of Animal Science, \\ Blvd. Ilinden, 92A; P.O. box. 207, 1000 Skopje, Republic of Macedonia, \\ tosokostadinov@gmail.com
}

\begin{abstract}
The aim of this paper is to incorporate new findings in the body of knowledge regarding entrepreneurship in rural areas of the Southwest Planning Region in the Republic of Macedonia. In that view interviewing was conducted with 14 owners of SMEs in rural areas who were presented four sets of statements that are important for understanding of the situation with entrepreneurship in the rural areas of the Southwest Planning Region in the Republic of Macedonia valued at five-degree scale from irrelevant to that of priority. One of the conclusions, by which the state of entrepreneurship and SMEs in the rural areas of the Southwest Planning Region of the Republic of Macedonia is assessed, based on empirical research and compared with the results of an identical research on rural entrepreneurship on the territory of the Republic of Macedonia, is that the rural entrepreneur from that region of the country has more affirmative attitudes towards entrepreneurship compared to the views regarding entrepreneurship from rural respondents on the whole territory of the Republic Of Macedonia. Развојни преоритети на регионот во наредниов период ce: 1) Economic development achieved through high-quality human capital knowledge and skills, developed small and medium-sized enterprises, and regional products recognizable by their geographic origin. 2) Region with a well developed and modern road network, sustainable water resources management, developed educational and ITC infrastructure. 3) Agricultural business based on modern concepts for producing recognizable regional agricultural produce and sustainable rural development based on modern knowledge and technology. 4) Attractive tourist destination with rich, varied and integrated tourist offer, based on sustainable use and protection of the cultural and natural heritage. 5) Environmentally clean area, with protected water, air and soil, and integrated waste management system and sustainable use of renewable energies. 6) Developed social infrastructure, with a network of efficient services for a dignified life and a decent standard of living.
\end{abstract}

Key words: Southwest planning region in the Republic of Macedonia; rural entrepreneurship, rural entrepreneurs; SMEs, rural areas

\section{ПРЕТПРИЕМНИШТВОТО ВО РУРАЛНИТЕ ЗАЕДНИЦИ ВО ЈУГОЗАПАДНИОТ ПЛАНСКИ РЕГИОН ВО РЕПУБЛИКА МАКЕДОНИЈА}

Целта на овој труд е да се вклучат нови наоди во корпусот на знаење за претприемништвото во руралните средини во регионот на Југозападниот плански регион во Република Македонија. Во тој поглед беше спроведено интервјуирање со 14 сопственици на мали и средни претпријатија (МСП) во руралните области на кои им беа презентирани четири групи на искази кои се важни за разбирање на ситуацијата со претприемништвото во руралните средини во областите на Југозападниот плански регион во Република Македонија во вредност од пет-степена скала од несоодветни до онаа на приоритет. Еден од заклучоците, со што состојбата на претприемништвото и малите и средни претпријатија во руралните области на Југозападниот плански регион на Република Македонија се оценува врз основа на емпириски истражувања и во споредба со резултатите од идентична истражување на руралните претприемништвото на територијата на Република Македонија, е дека руралните претприемач од овој регион на земјата има поафирмативни ставови кон претприемништвото споредено со ставовите кон преприемништвото во руралните подрачја во Република Македонија. Развојни преоритети на регионот во наредниов период се: 1) Економски развој да се постигне преку висок квалитет на човечкиот капитал знаења и вештини, да се развиваат мали и средни претпријатија, како и регионални производи препознатливи од страна на нивното географско потекло. 2) Регион со добро развиена и современа патна мрежа, одржливо управување со водните ресурси, развиени образовна и ИКТ инфраструктура. 3) Земјоделски бизнис врз основа на современите концепти за производство на препознатливи регионални 
земјоделски производи и одржлив рурален развој врз основа на современи знаења и вештини. 4) Атрактивната туристичка дестинација со богата, разновидна и интегрирана туристичка понуда, врз основа на одржливо користење и заштита на културното и природното наследство. 5) Еколошки чиста област, со заштита на водата, воздухот и почвата, како и интегриран систем за управување со отпад и одржливо користење на обновливите извори на енергија. 6) Развиена социјална инфраструктура, со мрежа на ефикасни услуги за достоинствен живот и пристоен стандард на живеење.

Клучни зборови: Југозападен плански регион: рурално претприемништво: рурален претприемач: МСП, рурални подрачја

\section{INTRODUCTION}

The geography of the Southwest Planning Region is a mix of mountains and valleys, whereas the predominant geographical feature are the mountains, locally with altitudes of more than $2000 \mathrm{~m}$. The largest valley in the region is the Ohrid-Struga valley, between the mountains of Jablanica and Galicica, part of which is the bottom the Ohrid Lake.

A total of 221.899 people or $11 \%$ of the population in the Republic of Macedonia live on an area of $3.340 \mathrm{sqkm}$ in 286 settlements. Regarding population distribution, there are great discrepancies between municipalities, as well as between settlements. More than $67 \%$ of the total population in the region live in three municipalities - Struga, Ohrid and Kichevo. The average population density of the Southwest Planning Region is 66.4 inhabitants/sqkm.

The region borders Albania to the west and to the south, and there are two border crossings on the territory of the region, namely: Sveti Naum and Kjafasan, both along Ohrid Lake, near the cites of Ohrid and Struga, respectively.

The Southwest Planning region has an abundance of water and forests, subject to a special regime of protection. The planning region is the most densely forested area in the country and holds $21 \%$ of the total area under forest, where coniferous and beech forests cover $66 \%$ of the total area. Most significant rivers are Treska and Crn Drim, which - through their hydro-power potential - have enabled the construction of three hydro-electric power plants in the region: Globochica and Debar Lake on Crn Drim and Kozjak on Treska

The Southwest Planning Region has about $10 \%$ of the total arable land in Macedonia, and most frequently produced crops are wheat, corn and potato, as well as apples, plums, pears and cherries.

The Southwest Planning Region has significant cultural and historical heritage. Ohrid with its surroundings is the centre of Slavic literacy; other noteworthy elements are the city infrastructure and the large number of churches and mosques.

The Ohrid Lake, as one of the oldest lakes in Europe, offers great potentials for development of summer tourism in the region. Out of the total number of tourist accommodations in Macedonia (26.503 beds), 16.400 - or $62 \%$ - are located in this planning region, most of which are in the two major tourist centres Ohrid and Struga, on the shores of Lake Ohrid. Furthermore, the planning region has abundant sources of game in the reserve Jasen, as well as on the hunting grounds Ramne, Trebolje and Tazhevo; auxiliary facilities for hunting are also available.

The Southwest Planning Region has a per capita GDP of $2.285 €$, which is approx. $30 \%$ less than the national average of the Republic of Macedonia. Hence, this region is ranked sixth of the eight planning regions in the country and contributes to $7.6 \%$ of the total Macedonian GDP. Economically most significant industries in the planning region are tourism, processing industry, energy, finances and partially agriculture and fishing. More than $47 \%$ of all visitors to Macedonia stay in that planning region, accounting for more than 1.300.000 overnight stay by foreign and domestic guests (65\% of the national total).

\section{MATERIALS AND METHODS}

The aim of this research is upon a base of relevant literature, documents and particularly an analysis of relevant sample of interviews (owners of 14 SMEs) to observe the conditions of the rural entrepreneurship in rural parts of the South-West Planning Region. The comparison of the obtained results with those relevant to the rural pats on the whole territory of the Republic of Macedonia (interviewed suitable sample of owners of 101 SMEs) puts mole light on the entrepreneurship in the researched region.

Several commonly used methods of economic analysis were applied in the composition of this paper, primarily the method of generalization and 
specialization, the method of induction and deduction, the statistical method and the comparative method.

\section{RESULTS AND DISCUSSION}

Survey respondents were given four sets of statements that are of relevance to the efforts of perceiving the situation of rural entrepreneurship in the Southwest Planning Region in Republic of Macedonia, valued at a five-degree scale from 1 - unimportant to 5 - priority (Table 1, 2, 3 and 4).

The results are compared to those obtained from rural areas on the territory of the Republic of Macedonia.

Compared with the results obtained from SMEs in rural areas throughout the Republic of Macedonia, SMEs in the rural areas of the Southwest Planning Region demonstrate considerably less obstacles their businesses face in their development.

Compared with the survey results of SMEs in rural areas on the whole territory of the Republic of Macedonia, SMEs in rural areas of the Southwest Planning Region show to be considerably more competitive on the market.

The results of the comparative research for the Southwest Planning Region indicated a significant degree of greater focus on plans for the businesses of SMEs in the rural areas for the future, compared to those SMEs in rural areas of the whole Republic of Macedonia.

The overall impression by the responses owners of SMEs in the rural areas of the Southwest Planning Region have given in relation to attitudes towards entrepreneurship is with significantly more positive attitudes than those expressed by respondents from rural areas on the territory of the Republic of Macedonia as a whole.

Table 1

Degree of agreement with the statements in terms of constraints on the development of enterprises using the arithmetic means

\begin{tabular}{lcc}
\hline \hline & Mean value (rural areas) \\
& Republic of Macedonia & Southwest planning region \\
\hline High rate of VAT & 3.60 & 3.41 \\
Problems with collection of claims & 3.65 & 3.59 \\
High rates of tax and employee contributions & 4.18 & 3.90 \\
Administrative difficulties and complex of procedures & 3.99 & 3.74 \\
Instability and ambiguity of the legislation & 4.02 & 3.88 \\
High interest rates on loans & 4.28 & 4.09 \\
Cost of energy & 3.92 & 3.81 \\
Cost of material, raw materials & 3.80 & 3.77 \\
Availability of funding sources & 3.99 & 3.66 \\
Loss of market in the former Yugoslavia & 3.03 & 2.72 \\
Unfair competition & 3.70 & 3.61 \\
Domestic competition & 3.86 & 3.65 \\
Obsolete technology & 3.40 & 3.30 \\
Quality of products & 3.30 & 3.22 \\
Products prices & 3.32 & 3.24 \\
Labour costs & 3.32 & 3.24 \\
Non-innovative products & 3.12 & 3.05 \\
Lack of funds for research and development & 2.84 & 2.68 \\
\hline \hline
\end{tabular}

Source: own calculations 
Table 2

Degree of agreement with the statements related to improvement of the competitiveness on the market using arithmetic means.

\begin{tabular}{lcc}
\hline \hline & \multicolumn{2}{c}{ Mean value (rural areas) } \\
\hline Improving the quality of products and services & 4.17 & 4.20 \\
Improving the promotion of products & 4.20 & 4.34 \\
Obtaining quality certifications & 4.03 & 4.21 \\
Professional consulting assistance & 3.46 & 3.64 \\
Improvement and education in the field of entrepreneurship & 3.83 & 3.96 \\
Improvement and education in the field of IT & 3.88 & 3.96 \\
Improvement and education in the field of management & 3.83 & 3.99 \\
Improvement and education in finance & 3.65 & 3.77 \\
Improvement and education in the field of sales & 3.89 & 3.96 \\
Improvement and education in marketing & 3.91 & 4.08 \\
Improvement and education in foreign languages & 3.38 & 3.33 \\
Association with companies in the sector for joint appearance on the market & 3.37 & 3.38 \\
Assistance from development programs through grants & 4.31 & 4.49 \\
Assistance from development programs through favorable loans & 4.30 & 4.39 \\
Assistance from development programs through guarantee funds & 3.80 & 3.89 \\
\hline \hline
\end{tabular}

Source: own calculations

Table 3

Degree of agreement with claims with regard to plans for the business future (arithmetic means)

\begin{tabular}{llc}
\hline \hline & \multicolumn{2}{c}{ Mean value (rural areas) } \\
\cline { 2 - 3 } & Republic of Macedonia & Southwest planning region \\
\hline Introducing new products or services & 4.08 & 4.29 \\
Sales on a new market & 3.37 & 3.48 \\
Exploring new markets & 3.32 & 3.44 \\
Search for new distribution channels & 3.61 & 3.88 \\
Expanding advertising and promotion & 3.87 & 3.97 \\
Investing in new equipment and machinery & 3.69 & 3.79 \\
Replacement of current equipment and machinery & 3.73 & 3.88 \\
Expansion of current facilities & 3.68 & 3.87 \\
Redesign/new arrangement of the current facilities & 3.42 & 3.44 \\
Search for additional financial capital & 3.92 & 4.14 \\
Computerization of current operations & 3.29 & 3.39 \\
Upgrading of computer systems & 3.38 & 3.38 \\
Redesign of work activities & 3.29 & 3.37 \\
Expanding the scope of work activities & 3.77 & 3.88 \\
Search for professional or technical advice & 3.45 & 3.55 \\
Additional engagement of staff specialists & 3.37 & 3.47 \\
Investing in staff training (elsewhere / not in the company) & 2.63 & 2.92 \\
\hline \hline
\end{tabular}

Source: own calculations 
Table 4

Degree of agreement with the statements in terms of attitudes to entrepreneurship, using the arithmetic means

\begin{tabular}{|c|c|c|}
\hline & \multicolumn{2}{|c|}{ Mean value (rural areas) } \\
\hline & Republic of Macedonia & Southwest planning region \\
\hline My business is the most important activity in my life & 4.13 & 4.37 \\
\hline I would do everything that is needed for my business to succeed & 4.18 & 4.29 \\
\hline I plan to sell my business at the end & 2.15 & 1.99 \\
\hline $\begin{array}{l}\text { I would like to significantly contribute to the community by developing a } \\
\text { successful business }\end{array}$ & 4.29 & 4.44 \\
\hline $\begin{array}{l}\text { I would prefer to have my own business than to earn higher wages working } \\
\text { for someone else }\end{array}$ & 4.78 & 4.93 \\
\hline $\begin{array}{l}\text { To run your own business is more important than have more time for the } \\
\text { family }\end{array}$ & 3.80 & 3.96 \\
\hline $\begin{array}{l}\text { I would prefer to have my own business than to have another promising } \\
\text { career }\end{array}$ & 4.08 & 4.82 \\
\hline $\begin{array}{l}\text { For the entrepreneur it is important to understand and accept the risk in } \\
\text { order to start and run a successful business }\end{array}$ & 4.26 & 4.43 \\
\hline $\begin{array}{l}\text { I am ready to get into conflict with my family for the sake of running my } \\
\text { business }\end{array}$ & 3.70 & 3.87 \\
\hline I would put my house mortgaged to acquire capital for my business & 3.52 & 3.66 \\
\hline $\begin{array}{l}\text { I would be ready to have less security for my family in order to run my } \\
\text { business }\end{array}$ & 3.67 & 3.85 \\
\hline I run my business to continue the family tradition & 3.34 & 3.54 \\
\hline I run my business to contribute to the welfare of my relatives & 3.52 & 3.67 \\
\hline I run my business to live in a place that my family likes & 3.47 & 3.65 \\
\hline I run my business to improve the status and prestige of my family & 4.02 & 4.31 \\
\hline I run my business to have more flexibility in my personal and family life & 4.08 & 4.32 \\
\hline
\end{tabular}

Source: own calculations

\section{CONCLUSION}

In comparison with the results obtained from data about SMEs in rural areas throughout the Republic of Macedonia, SMEs in the rural areas of the Southwest Planning Region considerably less face pronounced businesses obstacles in their development.

Compared with the results the survey of SMEs in rural areas on the whole territory of the Republic of Macedonia, SMEs in the rural areas of the Southwest Planning Region are show to be considerably more competitive on the market.

The results of the comparative study demonstrated a significant degree of greater focus on plans for the businesses of SMEs in the rural areas of the
Southwest Planning Region for the future, compared to SMEs in rural areas of the Republic of Macedonia.

Generally speaking the responses from owners of SMEs in the rural areas of the Southwest Planning Region regarding attitudes towards entrepreneurship indicate significantly more positive attitudes than those expressed from rural areas throughout the territory of the Republic of Macedonia.

The following are the development priorities of the Southwest region for the coming period:

1) Economic development achieved through high-quality human capital knowledge and skills, developed small and medium-sized enterprises, 
and regional products recognizable by their geographic origin.

2) Region with a well developed and modern road network, sustainable water recourses management, developed educational and ITC infrastructure.

3) Agricultural business based on modern concepts for producing recognizable regional agricultural produce and sustainable rural development based on modern knowledge and technology.

4) Attractive tourist destination with rich, varied and integrated tourist offer, based on sustainable use and protection of the cultural and natural heritage.

5) Environmentally clean area, with protected water, air and soil, integrated waste management system and sustainable use of renewable energies.

6) Developed social infrastructure, with a network of efficient services for a dignified life and a decent standard of living.

\section{REFERENCES}

[1] Janko Belak et al. (1993): Podjetništvo, politika podjetja in menagement, Založba Obzorja, Maribor.

[2] P. Burns (2001): Enterprise and Small Business, Palgrave Macmillan, London.

[3] D. W. Bygrave, A. Zacharakis: The portable MBA in Entrepreneurship, Fourth edition, John Wiley\&Son. Inc: Hoboken, New Jersey.

[4] ИСПИ (1998): Стратегија, политика и управување со развојот на руралните средини во Република Македонија, Трибина македонска, Скопје.

[5] T. Kostadinov, G. Cilev, N. Nikolova (2008): Small and Medium-Sized Enterprises in the Field of Agriculture in the Republic of Macedonia between Competitiveness Based Strategies and the Blue Ocean Strategy, Proceedings. International Conference for Entrepreneurship Innovation and Regional Development, Skopje-Ohrid.

[6] T. Kostadinov (2011): Влијанието на претприемништвото врз руралниот развој на Република Македонија, докторска дисертација, Економски институт, Скопје

[7] Ž. Pavić (2008): Poduzetništvo mladih i nova ekonomija, Ekonomski vjesnik, No. 1-2, Zagreb.

[8] Sara Carter, Dylan Jones-Evans (2000): Enterprise and Small Business, Prentice Hall, London.

[9] N. C. Siropolis (1995): Menadžment malog poduzeća, 4 izdanje, MATE, Hrvatska Obrtnička komora, Zagreb. 